\title{
REPRESENTASI MATEMATIKA AL-QUR'AN MELALUI TEORI GRAF
}

\author{
Oleh : Nursupiamin \\ Prodi Tadris Matematika FTIK IAIN Palopo \\ email: nursupia@gmail.com
}

\begin{abstract}
Abstrak :
Dalam Al-Qur'an, Allah SWT menyajikan begitu banyak isyarat salah satunya hitungan atau matematika. Pada tulisan ini, akan dipaparkan representasi matematika Al-Qur'an melalui teori graf khususnya yang berkaitan dengan surah prima atau surah Al-Qur'an yang jumlah ayatnya merupakan bilangan prima. Adapun hasil yang diperoleh berupa digraph dengan 29 simpul terpencil (29 graf kosong) dan 3 simpul membentuk sebuah graf sederhana yang memiliki makna diantaranya : (1) Persamaan yang terkandung antara surah Al-Mumtahanah (surah ke 60), surah Ar-Ra'd (surah ke 13), dan surah Az-Zukhruf (surah ke 43) adalah untuk menjauhi atau tidak bergaul dengan orang-orang yang tidak beriman kepada Allah swt dan rasulNya dan mencegah perbuatan yang mungkar; (2) Bila dipandang secara geometri, besarnya sudut yang terbentuk mendekati $90^{\circ}$ dan memiliki kemiripan bentuk dengan segitiga siku-siku; (3) Bila dipandang secara aljabar, jika ketiga titik $(60,13),(13,43)$, dan $(43,89)$ dinyatakan sebagai angka 601313434389, 60134389, 6013, 1343, dan 4389 maka angka tersebut merupakan kelipatan dari bilangan prima khusus seperti 7, 17 dan 19; dan (4) Bila dipandang secara teori graf, digraph yang terbentuk membuktikan bahwa untuk graf berarah pada digraph surah prima Al-Qur'an menunjukkan banyaknya simpul yang berderajat ganjil selalu genap. Sehingga representasi graf pada surah Al-Qur'an yang memiliki jumlah ayat bilangan prima menunjukkan bukti bahwa Al-Qur'an diturunkan dengan aturan tertentu yang menguak ada matematika dalam AlQur'an.
\end{abstract}

Kata Kunci : Matematika Al-Qur'an, Bilangan Prima, Teori Graf

\section{A. Pendahuluan}

Matematika merupakan salah satu pelajaran di tingkat sekolah yang dianggap memiliki peranan yang sangat penting khususnya dalam hal meningkatkan kualitas SDM. Dengan belajar matematika, peserta didik dibekali dengan kemampuan berpikir logis, analitis, sistematis, kritis, kreatif, serta kemampuan bekerjasama, sehingga siswa dapat memahami dan memecahkan masalah dengan baik. Sehingga berdampak kepada pembentukan pola pikir dalam pemahaman suatu pengertian maupun dalam penalaran suatu hubungan di antara pengertian-pengertian itu. Oleh karena itu, matematika sangat diperlukan baik untuk kehidupan sehari-hari maupun dalam menghadapi kemajuan IPTEK sehingga 
matematika perlu dibekalkan kepada setiap peserta didik sejak SD, bahkan sejak TK (dalam Herman Hudojo, 2005: 35). Penjelasan tersebut juga sesuai dengan pendapat Suherman (2001 : 53-54) bahwa melalui pembelajaran matematika, peserta didik dibiasakan untuk memperoleh pemahaman melalui pengalaman tentang sifatsifat yang dimiliki dari sekumpulan objek (abstrak). Dengan pengamatan diharapkan peserta didik mampu menangkap pengertian suatu konsep.

Di dalam Al-Qur'an, Allah SWT menyajikan begitu banyak isyarat salah satunya yang berkaitan dengan hitungan atau matematika. Perhitungan atau Matematika dapat memberikan kontribusi dan inspirasi yang cukup besar dalam kemajauan diberbagai bidang. Menurut Afzalur Rahman (2000 : 100) bahwa selain masalah umum dalam kehidupan, Al-Qur'an membahas matematika lebih khusus tentang perkalian dan perhitungan bilangan dalam berbagai peristiwa dan berbagai konteks. Pengetahuan mengenai matematika dan kekuasaan yang akhirnya matematika merupakan salah satu kekuatan utama pembentukan konsepsi tentang alam suatu hakekat dan tujuan manusia dalam kehidupannya. Seperti yang dikemukakan Morris Kline (dalam Lisnawati Simanjuntak, 1993: 64) bahwa jatuh bangunnya negara dewasa ini tergantung dari kemajuan di bidang matematika. Hal tersebut juga ditegaskan Hanna Djumhana Bastaman (2005 : 19) bahwa para ilmuan, pengajar, pelajar, dan kegiatan belajar mengajar mendapat tempat terhormat dalam Islam serta merupakan peluang besar untuk meraih pahala dan rahmat Ilahi, sebagaimana firman Allah dalam QS. al-Mujaadalah/58:11.

Berbicara tentang ilmu pengetahuan, Al Qur'an telah memberikan kepada manusia kunci ilmu pengetahuan tentang dunia dan akhirat serta menyediakan peralatan untuk mencari dan meneliti segala sesuatu agar dapat mengungkap dan mengetahui keajaiban dari kedua dunia itu (Afzalur Rahman, 1992: 12). Secara umum beberapa konsep dari disiplin ilmu telah dijelaskan dalam Al-Qur'an, salah satunya adalah matematika. Konsep dari disiplin ilmu matematika serta berbagai cabangnya yang ada dalam AlQur'an di antaranya adalah masalah logika, pemodelan, statistik, teori graf, dan lain-lain. Matematika yang biasanya diidentikkan dengan istilah ilmu pasti. Berbicara tentang ilmu pasti, tentunya gelar tersebut sepantasnya dijuluki untuk kitab umat Islam yaitu Al-Quran. Hal ini disebabkan, Al-Quran tidak ada keraguan apapun di dalamnya, sebagaimana yang tercantum dalam surat AlBaqarah/2: 2 . 
41 | al-Khwarizmi, Volume III, Edisi 2, Oktober 2015, Hal. 39 - 56

Al-Qur'an merupakan mu'jizat yang diturunkan Allah SWT kepada Nabi Muhammad SAW melalui malaikat jibril sebagai kitab suci umat islam yang mengandung petunjuk dan bimbingan untuk selalu berada pada jalan yang benar. Secara leksikal, kata Qur'an mengandung arti "bacaan" dan baru pada perkembangannya kemudian dianggap merujuk kepada arti "teks yang dibaca"(dalam Muhammad Abdul Halim diterjemahkan oleh Rofik Suhud, 2002:14). Sedangkan menurut Ali ash-Shabuni (dalam Mashuri Sirojuddin Iqbal dan Ahmad Fudloli, 1989 : 3), Al-Qur'an adalah kalamullah (firman Allah) yang mengandung mukjizat yang diturunkan kepada penutup para nabi dan rasul, dengan perantaraan yang dapat dipercaya yaitu malaikat Jibril, yang ditulis dalam mushaf dan diriwayatkan kepada kita secara mutawwatir, serta diperintahkan membacanya, diawali dengan surat al-Fatihah/1 dan diakhiri dengan surat an-Nas/114. Selain itu, Komaruddin Hidayat (1996 : 15) mengatakan Al-Qur'an adalah kitab suci yang memiliki dua karakter; yaitu Karakter Sentrifugal dan Karakter Sentripetal. Karakter pertama adalah karakter Al-Qur'an yang membuka ruang penafsiran bagi siapapun yang membacanya. Al-Qur'an menyediakan dirinya untuk ditafsiri dengan varian (metodologi) yang beragam. Sementara karakter yang kedua, Al-Qur'an selalu menjadi ruang kembali dari setiap penafsiran.

Bagi seorang muslim dalam melakukan interpretasi terhadap Al-Qur'an merupakan hal dalam memahami pesan yang Allah SWT berikan sebagai petunjuk dalam berjalan di muka bumi ini. Posisi manusia dengan segala kehebatannya hanya dapat memaknainya pada taraf relatif saja, sementara derajat kesempurnaan hanyalah merupakan rahasia Allah swt.

Struktur keilmuan inilah yang disebut dengan integratif interkonektif. Integrasi diartikan sebagai keterpaduan kebenaran wahyu (firman Allah SWT) dengan bukti-bukti yang ditemukan di alam semesta. Sedangkan interkoneksi adalah keterkaitan satu pengetahuan dengan pengetahuan yang lain akibat adanya hubungan yang saling mempengaruhi.

Pada kajian ini, peneliti mencoba merepresentasikan matematika Al-Qur'an melalui teori graf yang merupakan salah satu cabang matematika yang dikenalkan pada tahun 1736 oleh seorang matematikawan yang terkenal dari Swiss yang bernama Euler. Teori ini muncul untuk memecahkan teka-teki masalah jembatan Konigsberg dimana Konigsberg merupakan suatu kota di Prusia bagian timur Jerman. 


\section{B. Kajian Pustaka}

\section{Kajian Riset Sebelumnya}

Pada dasarnya penelitian yang berkaitan dengan aplikasi atau penerapan graf dan matematika Al-Qur'an sudah banyak diantaranya:

a) Penelitian yang dilakukan oleh Filly Candra Nore pada tahun 2011 dengan judul "Pewarnaan Graf Terhadap Penjadwalan Penitipan Anak".

b) Penelitian yang dilakukan oleh Wiwit Kurnia Sari pada tahun 2010 dengan judul "Representasi Digraph Untuk Nomor Surat Dan Banyak Ayat Al-Qur'an".

c) Penelitian yang dilakukan oleh Nisva Laila Mauluddiana tahun 2015 dengan judul "Pengaruh Pembelajaran Dengan Pendekatan Interkoneksi Matematika-Al-Qur'an Pada Ayat-Ayat Pilihan Dengan Pokok Bahasan Himpunan Terhadap Hasil Belajar Matematika Siswa Kelas VII MTs Al-Umron Bendosewu Kabupaten Blitar".

d) Penelitian yang dilakukan oleh Tri Lailatin Mubarokah tahun 2014 dengan judul "Penerapan Pembelajaran Matematika Berorientasi Dalil Al-Qur'an Untuk Meningkatkan Hasil Belajar Siswa Pada Materi Himpunan Kelas VII-B MTs Al-Umron Bendosewu Kab.Blitar".

e) Penelitian yang dilakukan oleh Annisah Kurniati tahun 2014 dengan judul "Interkoneksi Pembelajaran Aljabar Linear Elementer Dengan Islam Dan Manfaat Serta Aplikasinya Dalam Kehidupan”.

Berdasarkan hasil-hasil penelitian di atas, dapat disimpulkan bahwa penelitian yang dilakukan oleh penulis berbeda dengan penelitian sebelumnya.

2. Kajian Teoritis Teori Graf

Dalam bidang matematika, teori graf merupakan suatu teori yang dapat memodelkan suatu permasalahan dalam bentuk titik dan garis (sisi). Teori ini pertama kali diterapkan pada tahun 1736 melalui permasalahan jembatan Konigsberg berikut :

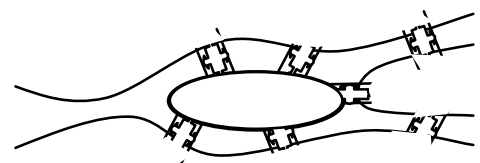

Gambar 1 : Jembatan Konigsberg 
43 | al-Khwarizmi, Volume III, Edisi 2, Oktober 2015, Hal. 39 - 56

Permasalahannya adalah dapatkah seseorang melewati setiap jembatan tepat sekali dan kembali lagi ke posisi semula?. Sebagian penduduk kota sepakat bahwa memang tidak mungkin melalui setiap jembatan itu hanya sekali dan kembali lagi ke tempat asal keberangkatan, tetapi mereka tidak dapat menjelaskan mengapa demikian jawabannya, kecuali dengan cara coba-coba.

Seorang matematikawan Swiss, Leonard Euler, merupakan orang pertama yang menemukan jawaban atas permasalahan itu dengan pembuktian melalui pemodelan ke dalam graf. Jawaban yang dikemukakan oleh Euler adalah seseorang itu tidak mungkin melalui ke tujuh jembatan itu masing-masing satu kali dan kembali lagi ke tempat asal keberangkatan jika derajat setiap simpul tidak seluruhnya genap. Dimana daratan (titik-titik yang dihubungkan oleh jembatan) dinyatakannya sebagai titik yang disebut simpul (vertex) diberi label huruf $A, B, C$, dan $D$. Jembatan dinyatakan sebagai garis yang disebut sisi (edge) dan yang dimaksud dengan derajat adalah banyaknya garis yang bersisian dengan titik (simpul). Graf yang dibuat oleh Euler diperlihatkan pada Gambar 2.2 berikut:

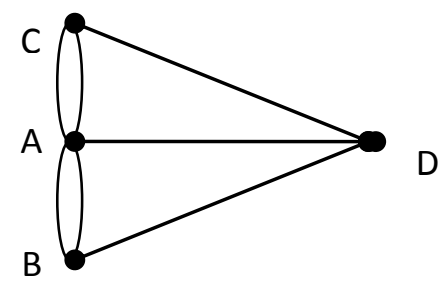

Gambar 2 : Representasi Jembatan Konigsberg dengan Graf

Pada tahun 1847, G. R. Kirchoff (1824 - 1887) berhasil mengembangkan teori pohon (Theory of trees) yang digunakan dalam persoalan jaringan listrik. Sepuluh tahun kemudian, A. Coyley (1821 - 1895) juga menggunakan konsep pohon untuk menjelaskan permasalahan kimia yaitu hidrokarbon. Pada masa Kirchoff dan Coyley juga telah lahir dua hal penting dalam teori graf. Salah satunya berkenaan dengan konjektur empat warna, yang menyatakan bahwa untuk mewarnai sebuah atlas cukup dengan menggunakan empat macam warna sedemikian hingga tiap negara yang berbatasan akan memiliki warna yang berbeda. 
Berikut dipaparkan secara singkat beberapa graf khusus :

a) Graf Kosong (Null graph atau Empty graph). Graf yang himpunan sisinya merupakan himpunan kosong dinamakan graf kosong, ditulis sebagai $\mathrm{Nn}$ dalam hal ini $\mathrm{n}$ adalah jumlah simpul.

b) Graf Lengkap (Complete Graph). Graf lengkap ialah graf sederhana yang setiap simpulnya mempunyai sisi ke semua simpul lainnya. Graf lengkap dengan $n$ buah simpul dilambangkan dengan $K_{n}$. Jumlah sisi pada graf lengkap yang terdiri dari $n$ buah simpul adalah $n(n-1) / 2$.

c) Graf Lingkaran. Graf lingkaran adalah graf sederhana yang setiap simpulnya berderajat dua. Graf lingkaran dengan $n$ simpul dilambangkan dengan $C_{n}$.

d) Graf Teratur (Regular Graph). Graf teratur adalah graf yang setiap simpulnya mempunyai derajat yang sama. Apabila derajat setiap simpul adalah $r$, maka graf tersebut disebut sebagai graf teratur derajat $r$. Jumlah sisi pada graf teratur adalah $n r / 2$.

e) Graf Berbobot (Weighted Graph). Graf berbobot adalah graf yang setiap sisinya diberi sebuah bobot pada tiap sisi. Pada Graf ini banyak digunakan untuk menyatakan jarak antar dua buah kota, biaya perjalanan antara dua buah kota, waktu tempuh, ongkos produksi, dan lain-lain. Bobot pada tiap sisi dapat berbeda-beda bergantung pada masalah yang dimodelkan dengan graf. Nama lain graf berbobot adalah graf berlabel.

f) Graf Bipartit (Bipartite Graph). Graf $G$ yang himpunan simpulnya dapat dipisah menjadi dua himpunan bagian $V_{1}$ dan $V_{2}$, sedemikian sehingga setiap sisi pada $G$ menghubungkan sebuah simpul di $V$ ke sebuah simpul di $V_{2}$ disebut graf bipartit dan dinyatakan sebagai $G\left(V_{1}, V_{2}\right)$. Jika setiap simpul $V_{1}$ bertetangga dengan semua simpul di $V_{2}$, maka $G\left(V_{1}, V_{2}\right)$ disebut graf bipartit lengkap yang dilambangkan $K_{m, n}$.

g) Graf Platonik. Graf platonik adalah graf yang berasal dari penggambaran bangun ruang, dimana titik sudut merupakan simpul, dan rusuk merupakan sisi.

h) Graf Roda (Wheels). Graf Roda adalah graf lingkaran yang setiap simpulnya dihubungkan dengan simpul di tengah lingkaran. Dinotasikan dengan W 
45 | al-Khwarizmi, Volume III, Edisi 2, Oktober 2015, Hal. 39 - 56

i) Graf Lintasan (Paths). Graf lintasan adalah graf yang bentuknya menyerupai garis lurus, jika $n$ adalah banyaknya simpul dan $n$ banyaknya sisi maka $\mathrm{m}=\mathrm{n}-1$, dinotasikan dengan $\mathrm{P}_{\mathrm{n}}$.

j) Graf Isomorfik. Dua buah graf yang sama tetapi secara geometri berbeda disebut graf yang saling isomorfik. Dua buah graf yang isomorfik adalah graf yang sama, kecuali penamaan simpul dan sisinya saja yang berbeda. Ini berarti sebuah graf dapat digambarkan dalam banyak cara. Jadi, dua buah graf, $G 1$ dan $G 2$ dikatakan isomorfik jika terdapat korespondensi satusatu antara simpul-simpul keduanya dan antara sisi-sisi keduaya sedemikian sehingga jika sisi $e$ bersisian dengan simpul $u$ dan $v$ di $G 1$, maka sisi $e$ ' yang berkoresponden di $G 2$ harus bersisian dengan simpul $u$ ' dan v' yang di $G 2$.

k) Graf Terhubung (Connected Graph). Graf tak-berarah $G$ disebut graf terhubung (connected graph) jika untuk setiap pasang simpul $v i$ dan $v j$ di dalam himpunan $V$ terdapat lintasan dari $v i$ ke $v j$ (yang juga harus berarti ada lintasan dari vj ke vi). Jika tidak, maka $G$ disebut graf tak-terhubung (disconnected graph). Yang perlu diketahui bahwa graf yang hanya terdiri atas satu simpul saja (tidak ada sisi) juga dikatakan juga graf terhubung, karena simpul tunggalnya terhubung dengan dirinya sendiri. Graf berarah $G$ dikatakan terhubung jika graf tak-berarahnya terhubung (graf tak-berarah dari $G$ diperoleh dengan menghilangkan arahnya). Keterhubungan dua buah simpul pada graf berarah dibedakan menjadi terhubung kuat dan terhubung lemah. Sedangkan graf berarah $G$ disebut graf terhubung kuat (strongly connected graph) apabila untuk setiap pasang simpul sembarang $v i$ dan $v j$ di $G$ terhubung kuat. Jika tidak, $G$ disebut graf terhubung lemah.

1) Upagraf (Subgraph) dan Komplemen Upagraf. Misalkan $G=$ $(V, E)$ adalah sebuah graf. $G 1=(V 1, E 1)$ adalah upagraf (subgraph) dari $G$ jika $V 1 \subseteq V$ dan $E 1 \subseteq E$. Sedangkan komplemen dari upagraf $G 1$ terhadap graf $G$ adalah graf $G 2=$ $(V 2, E 2)$ sedemikian sehingga $E 2=E-E 1$ dan $V 2$ adalah himpunan simpul yang anggota-anggota $E 2$ bersisian dengannya.

m)Upagraf Merentang (Spanning Subgraph). Upagraf G1 = $(\mathrm{V} 1, \mathrm{E} 1)$ dari $\mathrm{G}=(\mathrm{V}, \mathrm{E})$ dikatakan upagraf merentang jika $\mathrm{V} 1=$ V (yaitu G1 mengandung semua simpul dari G).

n) Graf Planar (Planar Graph) dan Graf Bidang (Plane Graph). Graf yang dapat digambarkan pada bidang datar dengan sisi-sisi 
tidak saling memotong disebut sebagai graf planar, jika tidak, ia disebut graf tak-planar. Graf planar yang digambarkan dengan sisi-sisi yang tidak saling berpotongan disebut graf bidang (plane graf). Sisi-sisi pada graf planar membagi bidang menjadi beberapa wilayah (region) atau muka (face).

o) Lintasan dan Sirkuit Euler. Lintasan Euler ialah lintasan yang melalui masing-masing sisi di dalam graf tepat satu kali. Sirkuit Euler ialah sirkuit yang melewati masing-masing sisi tepat satu kali. Graf yang mempunyai sirkuit Euler disebut graf Euler dan graf yang mempunyai lintasan Euler dinamakan juga graf semiEuler. Graf yang memiliki sirkuit Euler pasti mempunyai lintasan Euler, tetapi tidak sebaliknya.

p) Lintasan dan Sirkuit Hamilton. Lintasan Hamilton ialah lintasan yang melalui tiap simpul di dalam graf tepat satu kali. Sirkuit Hamilton ialah sirkuit yang melalui tiap simpul di dalam graf tepat satu kali, kecuali simpul asal (sekaligus simpul akhir) yang dilalui dua kali. Graf yang memiliki sirkuit Hamilton dinamakan graf Hamilton, sedangkan graf yang hanya memiliki lintasan Hamilton disebut graf semi-Hamilton.

q) Graf Dual. Misalkan sebuah graf planar G yang direpresentasikan sebagai graf bidang, mempunyai suafu graf $\mathrm{G}^{*}$ yang secara geometri merupakan dual dari graf planar tersebut dengan cara sebagai berikut:

i. Buat sebuah simpul $\mathrm{v}^{*}$ yang merupakan simpul untuk $\mathrm{G}^{*}$ pada setiap wilayah muka $\mathrm{f}$ di G.

ii. Untuk setiap sisi e di $\mathrm{G}$, tarik sisi e* (yang menjadi sisi $\left.\mathrm{G}^{*}\right)$ yang memotong sisi e tersebut. Hubungkan simpulsimpul $\mathrm{v}^{*}$ yang telah dibuat sebelumnya.

Graf $\mathrm{G}^{*}$ yang terbentuk dengan cara penggambaran demikian disebut graf dual (atau tepatnya dual geometri) dari graf $\mathrm{G}$.

r) Bertetangga (Adjacent). Dua buah simpul pada graf tak berarah $G$ dikatakan bertetangga bila keduanya terhubung langsung dengan sebuah sisi. Pada graf berarah, jika busur $\left(v_{j}, v_{k}\right)$ maka $v_{j}$ dikatakan bertetangga dengan $v_{k}$ dan $v_{k}$ dikatakan tetangga dari $v_{j}$.

s) Bersisian (Incient). Untuk sembarang sisi e $=\left(v_{j}, v_{k}\right)$, sisi e dikatakan bersisian dengan simpul $v_{j}$ dan $v_{k}$.

t) Simpul Terpencil (Isolated Vertex). Simpul terpencil adalah simpul yang tidak mempunyai sisi yang bersisian dengannya. Atau, dapat juga dinyatakan simpul yang tidak satupun bertetangga dengan simpul lainnya. 
47 | al-Khwarizmi, Volume III, Edisi 2, Oktober 2015, Hal. 39 - 56

u) Derajat (Degree). Derajat suatu simpul adalah jumlah sisi yang bersisian dengan simpul tersebut. Dinotasikan sebagai d(v) yang menyatakan derajat simpul v. Simpul terpencil adalah simpul dengan $\mathrm{d}(\mathrm{v})=0$, karena tidak ada satupun sisi yang bersisian dengan simpul tersebut. Sisi gelan atau loop dihitung $\mathrm{d}(\mathrm{v})=2$. Simpul yang berderajat satu disebut anting-anting (pendant vertex). Dengan kata lain anting - anting hanya bertetangga dengan sebuah simpul. Pada graf berarah, derajat simpul v dinyatakan dengan $\mathrm{d}_{\text {in }}(\mathrm{v})$ dan $\mathrm{d}_{\text {out }}(\mathrm{v})$, yang dalam hal ini $\mathrm{d}_{\text {in }}(\mathrm{v})=$ derajat masuk ( in-degree) $=$ jumlah busur yang masuk ke simpul $\mathrm{v}$ dan $\mathrm{d}_{\text {out }}(\mathrm{v})=$ derajat keluar (out-degree) $=$ jumlah busur keluar dari simpul v. Sehingga $d(v)=d_{\text {in }}(v)+d_{\text {out }}(v)$. Pada graf berarah $G=(V, E)$ selalu berlaku hubungan:

$\sum \mathrm{d}_{\text {in }}(v)=\sum_{v \in v} \mathrm{~d}_{\text {out }}(v)=|E|$

Pada Lemma Jabat Tangan dikatakan bahwa jumlah derajat semua simpul pada suatu graf yaitu genap,dimana dua kali jumlah sisi pada graf tersebut. Dengan kata lain, jika $G=(V, E)$, maka : $\sum_{v e v} \mathrm{~d}(\mathrm{v})=2|E|$. Lemma Jabat Tangan juga benar untuk graf berarah, yang dalam hal ini $\mathrm{d}(v)=\mathrm{d}_{\text {in }}(v)+\mathrm{d}_{\text {out }}(v)$. Akibat, dari lemma jabat tangan, untuk sembarang graf $G$, banyaknya simpul yang berderajat ganjil selalu genap.

v) Lintasan (Path). Lintasan yang panjangnnya $n$ dari sampul awal $v_{0}$ ke simpul tujuan $v n$ dalam graf $G$ ialah barisan yang berselang - seling simpul - simpul dan sisi - sisi yang berbentuk $v_{0}, e_{1}, v_{1}, e_{2}, v_{2, \ldots}, v n-1, e_{n}, v_{n}$ sedemikian sehingga $e_{1}=$ $\left(v_{0}, v_{l}\right), e_{2}=\left(v_{l}, v_{2}\right), \ldots, e_{n}=\left(v_{n-l}, v_{n}\right)$ adalah sisi - sisi dari graf $G$ . Pada graf sederhana, maka cukup menuliskan lintasan sebagai barisan simpul-simpul saja: $v_{0}, v_{1}, v_{2, \ldots}, v_{n-1}, v_{n}$, karena antara dua buah simpul berurutan di dalam lintasan tersebut hanya ada satu sisi. Pada graf yang mengandung sisi ganda, harus menulis lintasan sebagai barisan berselang-seling antara simpul dan sisi menghindari kerancuan sisi mana dari sis-sisi ganda yang dilalui. Simpul dan sisi yang dilalui di dalam lintasan boleh berulang. Sebuah lintasan dikatakan lintasan sederhana (simple peth) jika semua simpulnya berbeda (setiap sisi yang dilalui hanya satu kali ). Lintasan yang berawal dan berakhir pada simpul yang sama disebut lintasan tertutup ( closed path), sedangkan lintasan yang tidak berawal dan berakhir pada simpul yang sama disebut lintasan terbuka (open path). Panjang lintasan adalah jumlah sisi dalam lintasan tersebut. 
w) Cut-set. Cut-set dari graf terhubung $G$ adalah himpunan sisi yang bila dibuang dari $G$ menyebabkan $G$ tidak terhubung. Istilah lain dari cut-set adalah bridge atau jembatan, dimana bertugas menghubungkan dua buah subgraf. Cut-set sangat berperan besar dalam jaringan komunikasi dan jaringan transportasi.

\section{Metode Penelitian}

Adapun jenis penelitian ini adalah penelitian kepustakaan (library research) yang bermakna studi yang dilakukan dengan mengumpulkan teori dan informasi dengan bantuan bermacammacam material yang terdapat di ruangan perpustakaan, seperti buku-buku, majalah, dokumen, catatan dan kisah-kisah sejarah (Mardalis, 1989 : 28). Kajian ini bertujuan untuk menemukan interpretasi matematika Al-Qur'an melalui teori graf.

Sedangkan jenis data yang digunakan pada penelitian ini data deskriptif. Adapun teknik pengumpulan data yang digunakan pada penelitian ini adalah hasil kajian berupa hasil-hasil penelitian yang berkaitan dengan matematika Al-Qur'an dan aplikasi graf.

Langkah dalam melakukan penelitian ini dimulai dengan melakukan pengumpulan hasil penelitian atau hasil kajian yang berkaitan dengan matematika Al-Qur'an. Selanjutnya penulis mendata ruang lingkup dari hasil penelitian tersebut dan melakukan pengembangan kajian terhadap kajian yang belum tersentuh oleh peneliti lain. Adapun kajian ini terfokus pada surah prima. Dalam pelaksanaannya, peneliti merepresentasikan matematika Al-Qur'an melalui teori graf.

\section{Hasil Penelitian}

Berdasarkan prosedur penelitian, maka hasil penelitian dipaparkan sebagai berikut:

1. Mendata nomor surah dan jumlah ayat dalam Al-Qur'an seperti pada tabel berikut : 
49 | al-Khwarizmi, Volume III, Edisi 2, Oktober 2015, Hal. 39 - 56

Tabel 1: Nomor Surah dan Jumlah Ayat dalam Al-Qur'an

\begin{tabular}{|c|c|c|c|c|c|}
\hline $\begin{array}{c}\text { No. } \\
\text { surah }\end{array}$ & $\begin{array}{c}\text { Banyak } \\
\text { ayat }\end{array}$ & $\begin{array}{c}\text { No. } \\
\text { surah }\end{array}$ & $\begin{array}{c}\text { Banyak } \\
\text { ayat }\end{array}$ & $\begin{array}{c}\text { No. } \\
\text { surah }\end{array}$ & $\begin{array}{c}\text { Banyah } \\
\text { ayat }\end{array}$ \\
\hline 1 & 7 & 39 & 75 & 77 & 50 \\
\hline 2 & 286 & 40 & 85 & 78 & 40 \\
\hline 3 & 200 & 41 & 54 & 79 & 46 \\
\hline 4 & 176 & 42 & 53 & 80 & 42 \\
\hline 5 & 120 & 43 & 89 & 81 & 29 \\
\hline 6 & 165 & 44 & 59 & 82 & 19 \\
\hline 7 & 206 & 45 & 37 & 83 & 36 \\
\hline 8 & 75 & 46 & 35 & 84 & 25 \\
\hline 9 & 129 & 47 & 38 & 85 & 22 \\
\hline 10 & 109 & 48 & 29 & 86 & 17 \\
\hline 11 & 123 & 49 & 18 & 87 & 19 \\
\hline 12 & 111 & 50 & 45 & 88 & 26 \\
\hline 13 & 43 & 51 & 60 & 89 & 30 \\
\hline 14 & 52 & 52 & 49 & 90 & 20 \\
\hline 15 & 99 & 53 & 62 & 91 & 15 \\
\hline 16 & 128 & 54 & 55 & 92 & 21 \\
\hline 17 & 111 & 55 & 78 & 93 & 11 \\
\hline 18 & 110 & 56 & 96 & 94 & 8 \\
\hline 19 & 98 & 57 & 29 & 95 & 8 \\
\hline 20 & 135 & 58 & 22 & 96 & 19 \\
\hline 21 & 112 & 59 & 24 & 97 & 5 \\
\hline 22 & 78 & 60 & 13 & 98 & 8 \\
\hline 23 & 118 & 61 & 14 & 99 & 8 \\
\hline 24 & 64 & 62 & 11 & 100 & 11 \\
\hline 25 & 77 & 63 & 11 & 101 & 11 \\
\hline 26 & 227 & 64 & 18 & 102 & 8 \\
\hline 27 & 93 & 65 & 12 & 103 & 3 \\
\hline 28 & 88 & 66 & 12 & 104 & 9 \\
\hline 29 & 69 & 67 & 30 & 105 & 5 \\
\hline 30 & 60 & 68 & 52 & 106 & 4 \\
\hline 31 & 34 & 69 & 52 & 107 & 7 \\
\hline 32 & 30 & 70 & 44 & 108 & 3 \\
\hline 33 & 73 & 71 & 28 & 109 & 6 \\
\hline 34 & 54 & 72 & 28 & 110 & 3 \\
\hline 35 & 45 & 73 & 20 & 111 & 5 \\
\hline 36 & 83 & 74 & 56 & 112 & 4 \\
\hline 37 & 182 & 75 & 40 & 113 & 5 \\
\hline 38 & 88 & 76 & 31 & 114 & 6 \\
\hline & & & & & \\
\hline
\end{tabular}


2. Mendata surah dalam Al-Qur'an yang jumlah ayatnya merupakan bilangan prima

Berikut diperlihatkan surah dalam Al-Qur'an yang jumlah ayatnya merupakan bilangan prima.

Tabel 2: Daftar Surah Prima

\begin{tabular}{|c|c|c|c|}
\hline $\begin{array}{c}\text { Nomor } \\
\text { Surah }\end{array}$ & $\begin{array}{c}\text { Jumlah } \\
\text { Ayat }\end{array}$ & $\begin{array}{c}\text { Nomor } \\
\text { Surah }\end{array}$ & $\begin{array}{c}\text { Jumlah } \\
\text { Ayat }\end{array}$ \\
\hline 1 & 7 & 81 & 29 \\
\hline 10 & 109 & 82 & 19 \\
\hline 13 & 43 & 86 & 17 \\
\hline 26 & 227 & 87 & 19 \\
\hline 33 & 73 & 93 & 11 \\
\hline 36 & 83 & 96 & 19 \\
\hline 42 & 53 & 97 & 5 \\
\hline 43 & 89 & 100 & 11 \\
\hline 44 & 59 & 101 & 11 \\
\hline 45 & 37 & 103 & 3 \\
\hline 48 & 29 & 105 & 5 \\
\hline 57 & 29 & 107 & 7 \\
\hline 60 & 13 & 108 & 3 \\
\hline 62 & 11 & 110 & 3 \\
\hline 63 & 11 & 111 & 5 \\
\hline 76 & 31 & 113 & 5 \\
\hline
\end{tabular}

3. Menemukan Matematika Al-Qur'an dalam Representasi Bilangan Prima

Berdasarkan tabel 2 terlihat bahwa yang tergolong dalam surah prima ada surah ganjil dan surah genap. Dimana terdapat 32 surah yang merupakan surah prima, yang terdiri 17 surah ganjil (surah homogen) dan 15 surah genap (surah heterogen). Semakin jauh diselidiki terkuak ada rahasia secara matematik tentang surah prima yaitu

a) Gabungan jumlah nomor surah prima dan jumlah ayat dari surah prima merupakan kelipatan 17.

b) Gabungan jumlah nomor urut, nomor surah prima dan jumlah ayat dari surah prima merupakan kelipatan 19 . 
51 | al-Khwarizmi, Volume III, Edisi 2, Oktober 2015, Hal. 39 - 56

4. Graf dalam Matematika Al-Qur'an

Berdasarkan tabel 2 dibuat Digraph dari nomor surat prima dan banyak ayatnya dalam Al-Qur'an, maka nomor surat dan dan banyak ayat tersebut dinyatakan dalam bentuk titik (vertex), yaitu titik (a, b). Titik a menyatakan nomor surat dalam Al-Qur'an, sedangkan titik b menyatakan banyak ayat pada surat dalam AlQur'an. Titik (a, b) dalam digraph ini akan ditulis dalam bentuk $v_{a}$, maka akan terdapat 32 titik. Berikut ini adalah titik-titik yang terbentuk dari nomor surat prima dan banyak ayatnya dalam AlQur'an:

Tabel 3: Titik Dalam Digraph Surah Prima

\begin{tabular}{|l|l|l|l|}
\hline Nomor & Titik & Nomor & Titik \\
\hline 1 & $(1,7)$ & 17 & $(81,29)$ \\
\hline 2 & $(10,109)$ & 18 & $(82,19)$ \\
\hline 3 & $(13,43)$ & 19 & $(86,17)$ \\
\hline 4 & $(26,227)$ & 20 & $(87,19)$ \\
\hline 5 & $(33,73)$ & 21 & $(93,11)$ \\
\hline 6 & $(36,83)$ & 22 & $(96,19)$ \\
\hline 7 & $(42,53)$ & 23 & $(97,5)$ \\
\hline 8 & $(43,89)$ & 24 & $(100,11)$ \\
\hline 9 & $(44,59)$ & 25 & $(101,11)$ \\
\hline 10 & $(45,37)$ & 26 & $(103,3)$ \\
\hline 11 & $(48,29)$ & 27 & $(105,5)$ \\
\hline 12 & $(57,29)$ & 28 & $(107,7)$ \\
\hline 13 & $(60,13)$ & 29 & $(108,3)$ \\
\hline 14 & $(62,11)$ & 30 & $(110,3)$ \\
\hline 15 & $(63,11)$ & 31 & $(111,5)$ \\
\hline 16 & $(76,31)$ & 32 & $(113,5)$ \\
\hline
\end{tabular}

\section{Digraph Surah Prima}

Dalam pembahasan ini, keterhubungan antar titik dibuat sebuah aturan yaitu: titik ( $\mathrm{a}, \mathrm{b})$ akan adjacent to (bertetangga) titik (c, d) jika dan hanya jika $b=c$. Dan untuk bobot tiap sisi pada digraph tersebut adalah $\mathrm{b}=\mathrm{c}$. Digraph yang terbentuk dari nomor surat prima dan banyak ayatnya dalam Al-Qur'an membentuk digraph dengan 29 simpul terpencil (29 graf kosong) dan 3 simpul membentuk sebuah graf sederhana seperti yang terlihat pada gambar di bawah ini : 


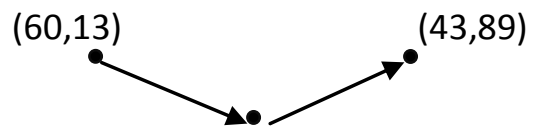

$(13,43)$

Gambar 1 : Graf Sederhana Surah Prima Al-Qur'an

Gambar 1 di atas memiliki makna terdapat diantaranya :

a) Surah Al-Mumtahanah (surah ke 60) yang artinya perempuan yang diuji. Arti surah ini diambil dari kata "Famtahinuuhunna" pada ayat 10 yang artinya "maka ujilah mereka". Surah Ar-Ra'd (surah ke 13) yang artinya guruh/petir. Kata guruh/petir dapat dilihat pada ayat 13 yang artinya "Dan guruh bertasbih sambil memujiNya". Adapun yang merupakan hal penting dari surah ini adalah bimbingan Allah swt kepada mahlukNya berkorelasi dengan hukum sebab akibat dimana Allah Maha Adil dalam menetapkan hukuman yang merupakan akibat keingkaran terhadap hukum Allah. Surah Az-Zukhruf (surah ke 43) yang artinya perhiasan. Kata perhiasan dapat dilihat pada ayat 35 yang menegaskan harta tidak dijadikan sebagai ukuran tinggi rendahnya status seseorang, harta hanyalah hiasan yang bersifat duniawi bukan kesenangan akherat. Adapun persamaan yang terkandung adalah untuk menjauhi atau tidak bergaul dengan orang-orang yang tidak beriman kepada Allah swt dan rasulNya dan mencegah perbuatan yang mungkar.

b) Bila dipandang secara geometri letak ketiga titik tersebut jelas terletak pada kuadran I dengan bentuk hampir seperti segitiga siku-siku. Dimana besarnya sudut yang terbentuk mendekati $90^{\circ}$ dan jarak antara titik $(60,13)$ dengan titik $(13,43)$ sama dengan 55,76 serta jarak antara titik $(13,43)$ dengan titik $(43,89)$ sama dengan 54,92 . Sehingga jarak antara titik $(60,13)$ dengan titik $(43,89)$ sama dengan 77,88 yang mendekati nilai 78,3 jika dianggap segitiga yang terbentuk sebagai segitiga siku-siku.

c) Bila dipandang secara aljabar yang dapat diperoleh dari gambar 1 adalah jika ketiga titik $(60,13),(13,43)$, dan $(43,89)$ dinyatakan sebagai angka 601313434389, maka angka ini merupakan kelipatan dari 17 dan 19. Jika ketiga titik $(60,13)$, $(13,43)$, dan $(43,89)$ dinyatakan sebagai angka 60134389 , maka angka ini merupakan kelipatan 7 dan 17. Sedangkan angka 6013 merupakan kelipatan 7, angka 1343 merupakan kelipatan 17, dan angka 4389 merupakan kelipatan 7,11, dan 19. 
53 | al-Khwarizmi, Volume III, Edisi 2, Oktober 2015, Hal. 39 - 56

d) Bila dipandang secara teori graf, digraph yang terbentuk dari gambar 1 memiliki $d_{\text {in }}=2$ dan $d_{\text {out }}=2$. Perolehan ini sesuai catatan bahwa pada graf berarah $G=(V, E)$ selalu berlaku hubungan:

$\sum \mathrm{d}_{\text {in }}(v)=\sum_{v e v} \mathrm{~d}_{\text {out }}(v)=|E|$

Dimana $|E|$ menyatakan jumlah sisi pada graf sederhana surah prima Al-Qur'an.

Sehingga berdasarkan Lemma Jabat Tangan untuk graf berarah diperoleh :

$\mathrm{d}(v)=\mathrm{d}_{\text {in }}(v)+\mathrm{d}_{\text {out }}(v)=4$

Akibat dari lemma jabat tangan ini terbukti bahwa untuk graf berarah pada digraph surah prima Al-Qur'an menunjukkan banyaknya simpul yang berderajat ganjil selalu genap.

Berdasarkan hasil di atas, representasi graf pada surah AlQur'an yang memiliki jumlah ayat bilangan prima menunjukkan bukti bahwa Al-Qur'an diturunkan dengan aturan tertentu yang menguak ada matematika dalam Al-Qur'an.

\section{E. Penutup}

Dengan merujuk pada hasil kajian yang telah diperoleh, maka representasi matematika Al-Qur'an melalui teori graf khususnya yang berkaitan dengan surah prima atau surah Al-Qur'an yang jumlah ayatnya merupakan bilangan prima. Adapun hasil yang diperoleh berupa digraph dengan 29 simpul terpencil (29 graf kosong) dan 3 simpul membentuk sebuah graf sederhana yang memiliki makna diantaranya. Persamaan yang terkandung antara surah Al-Mumtahanah (surah ke 60), surah Ar-Ra'd (surah ke 13), dan surah Az-Zukhruf (surah ke 43) adalah untuk menjauhi atau tidak bergaul dengan orang-orang yang tidak beriman kepada Allah swt dan rasulNya dan mencegah perbuatan yang mungkar.

1. Bila dipandang secara geometri, besarnya sudut yang terbentuk mendekati $90^{\circ}$ dan jarak antara titik $(60,13)$ dengan titik $(13,43)$ sama dengan 55,76 serta jarak antara titik $(13,43)$ dengan titik $(43,89)$ sama dengan 54,92 . Sehingga jarak antara titik $(60,13)$ dengan titik $(43,89)$ sama dengan 77,88 yang mendekati nilai 78,3 jika dianggap segitiga yang terbentuk sebagai segitiga siku-siku. 
Representasi Matematika Al-Quran ...| 54

2. Bila dipandang secara aljabar, jika ketiga titik $(60,13)$, $(13,43)$, dan $(43,89)$ dinyatakan sebagai angka 601313434389, maka merupakan kelipatan dari 17 dan 19. Jika dinyatakan sebagai angka 60134389, maka merupakan kelipatan 7 dan 17. Sedangkan angka 6013 merupakan kelipatan 7, angka 1343 merupakan kelipatan 17, dan angka 4389 merupakan kelipatan 7,11, dan 19.

3. Bila dipandang secara teori graf, digraph yang terbentuk membuktikan bahwa untuk graf berarah pada digraph surah prima Al-Qur'an menunjukkan banyaknya simpul yang berderajat ganjil selalu genap. 


\section{DAFTAR PUSTAKA}

Al-Athar, Daud. Perspektif Baru Ilmu Al-Qur'an. Bandung:

Pustaka Hidayah, 1979.

Bastaman, Hanna Djumhana. Integrasi Psikologi dalam Islam.

Yogyakarta: PustakaPelajar, 2005.

Fahmi Basya, Fahmi. Matematika Islam : Sebuah Pendekatan Rasional Untuk Yaqin. Jakarta : Penerbit Republika, 2004.

Gholam-Ali Haddad-Adel. Selalu Bersama Al-Qur'an : Agar Hidup Menjadi “Super". Jakarta : Penerbit Citra, 2012.

Halim, Muhammad Abdul. Understanding Qur'an: Themes and Style, diterjemahkan oleh Rofik Suhud dengan Judul Memahami Al-Qur'an: Pendekatan Gaya dan Tema. Bandung : Marja', 2002.

Hidayat, Komaruddin. Memahami Bahasa Agama, Jakarta: Paramadina, 1996.

Hidayat, Muhammad Taufik. Science Spirituality \& Qur'an, Cet. I; Bantul: Quantum Sinergis Media, 2011.

Hudojo, Herman. Pengembangan Kurikulum dan Pembelajaran Matematika,Malang: Universitas Negeri Malang, 2005.

Kurniati, Annisah. Interkoneksi Pembelajaran Aljabar Linear Elementer Dengan Islam Dan Manfaat Serta Aplikasinya Dalam Kehidupan. Jurnal Potensia vol.13 Edisi 2 Juli Desember 2014, h.167-176.

Mauluddiana, Nisva Laila. Pengaruh Pembelajaran Dengan Pendekatan Interkoneksi Matematika-Al-Qur'an Pada AyatAyat Pilihan Dengan Pokok Bahasan Himpunan Terhadap Hasil Belajar Matematika Siswa Kelas VII MTs Al-Umron Bendosewu Kabupaten Blitar. Tulungagung : IAIN, 2015.

Mubarokah, Tri Lailatin. Penerapan Pembelajaran Matematika Berorientasi Dalil Al-Qur'an Untuk Meningkatkan Hasil Belajar Siswa Pada Materi Himpunan Kelas VII-B MTs AlUmron Bendosewu Kab.Blitar. Tulungagung : IAIN, 2014.

Muftie, Arifin. Matematika Alam Semesta: Kodetifikasi Bilangan Prima Dalam Al-Qur'an. Bandung : Kiblat Buku Utama, 2004.

Munir, Rinaldi. Matematika Diskrit Ed. 3. Bandung : Informatika, 2010.

Nawawi, Rif'at Syauqi. Kepribadian Qur'ani. Jakarta : AMZAH, 2011.

Nore, Filly Candra. Pewarnaan Graf Terhadap Penjadwalan Penitipan Anak. Padang : Universitas Andalas, 2011. 
Nore, Filly Candra. Pewarnaan Graf Terhadap Penjadwalan

Penitipan Anak. Padang : Universitas Andalas, 2011.

Nursupiamin. Konsep Dasar Graf. Makassar : LIPa, 2011.

Rahman, Afzalur. Al-Qur'an Sumber Ilmu Pengetahuan. Jakarta : Rineka Cipta, 2000.

Sampayya, Abah Salma A. Keseimbangan Matematika Dalam AlQur'an. Jakarta : Republika, 2007.

Sari, Wiwit Kurnia. Representasi Digraph Untuk Nomor Surat Dan Banyak Ayat Al-Qur'an. Malang: Universitas Negeri Islam Maulana Malik Ibrahim, 2010.

Simanjuntak, Lisnawati. MetodeMengajarMatematika, Jakarta: RinekaCipta, 1993.

Soedjadi, Kiat Pendidikan Matematika di Indonesia, Departemen Pendidikan dan Kebudayaan Direktorat Jenderal Pendidikan Tinggi, 1999.

Suherman, Erman, dkk. Strategi Belajar Mengajar Kontemporer. Bandung: JICA, 2001.

Yusuf, Kadar M. Studi Al-Qur'an, Cet. I; Jakarta : Amzah, 2012. 